\title{
Management of Type II Odontoid Fractures OBAV: About A Series of 5 Cases and Literature Review
}

Noukhoum Koné ${ }^{1^{*}}$, Aderehim Haidara ${ }^{2}$, Marialaura Giamundo ${ }^{3}$ and Angelo Rusconi ${ }^{4}$

${ }^{1}$ Department of neurosurgery, Kiffa Hospital Center, Mailbox 4509 Kiffa, Mauritania

${ }^{2}$ Department of Neurosurgery, University Hospital Center of Bouaké, 01 Mailbox 1174 Bouaké Ivory Coast

${ }^{3}$ Neurocenter of Italian Switzerland, Civic Hospital of Lugano, Via Tesserete 46; 6900 Lugano, Switzerland

${ }^{4}$ Department of Orthopedics, Spinal Surgery, Cantonal Hospital, Residential School Road 2; 1700 Friborg, Switzerland

\section{Abstract}

Publication History:

Received: December 02, 2017

Through this single-center consecutive prospective study, we evaluated the results of 2 posteriors C1/ Accepted: February 13, 2018

C2 constructs procedure for Type II odontoid fractures OBAV. 5 adult patients were succefully treated Published: February 15, 2018

by Harms's technique and a novel C1 lateral mass/C2 laminar hooks procedure in posterior approach for

Type II odontoid fractures OBAV.

\section{Keywords:}

The mean follow-up was 10 months. All patients were male. The mean age was 49.2 years. Bony fusion and clinical outcome were favorables in all cases.

Cervical laminar hook, Odontoïde fracture, Posterior cervical

No neural or vascular damage related to theses techniques have been observed. Surgeons might instrumented fusion consider theses differents approachs techniques before realizing a treatment.

\section{Abbreviations}

CSF : Cerebrospinal Fluid; CT: Computerized Tomography; InI: Intentional Injury; MRI: Magnetic Resonance Imaging; mRS: modified Rankin Scale; MVA : Motor Vehicle Accident; OBAV: Fracture line Oblique from posterosuperior to anteroinferior; TOF: Type II Odontoid Fracture

\section{Introduction}

$25 \%$ of all cervical spine injuries affect the axis $[1,2]$, of wich odontoid fracture represent $10-15 \%$ [3]. These fractures were classified into three distinct types by Anderson and D'Alonzo [4] in 1974. Type I odontoid fractures are quite uncommon and involve an avulsion of the rostral-most portion of the dens. In contrast, Type II fractures are the most common odontoid fracture, occurring in $65 \%-74 \%$ of the cases $[4,5]$. The fracture line traverses the base of the odontoid process at the junction of the vertebral body. A lateral bending force has been proposed as the mechanism causing the development of Type II fractures [6]. Finally, Type III fractures actually extend into the body of the axis, frequently involving the superior articular surface. These fractures may be caused by a flexion moment through the occiput [6]. Management for odontoid fractures includes anterior odontoid screw fixation, posterior wiring and bone grafting of C1-2 (Gallie, Brooks-Jenkins), transarticular screw fixation (Magerl) [7] C1 lateral mass screw fixation described by differents authors: Goel and Laheri [8] (associated with a C-2 screw lamina, pars, or pedicle) in 1994, this technique was modified by Harms and Melcher [9] in 2001 to use polyaxial screws and rods instead of a plate. In 2012 Reis and al. [10] proposed a novel technique using opposing laminar hooks to form a claw at C-2 combined with C- 1 lateral mass screws ; as well as nonoperative strategies, such as immobilization by a halo vest and cervical collar [11]. A review of the literature shows that the best treatment strategy for Type II odontoid fractures remains controversial [12-14]. In this paper, we present five cases of Type II odontoid fractures (TOF) OBAV treated by Harm's technique [9] and a new $\mathrm{C} 1$ lateral mass/C2 laminar hooks procedure in posterior approach that we propose as an alternative procedure for the surgical management of TOF OBAV.

\section{Materials and Method}

\section{Patient demographics}

Patient Demographics. Five patients underwent Harms's technique and and a novel $\mathrm{C} 1$ lateral mass/C2 laminar hooks procedure in posterior approach for TOF OBAV. All patients were male. The average age was 49,2 years (range 16-75 years). The mean follow-up was 10 months. In $80 \%$ of the cases, fractures occurred in a high energy trauma (Intentional Injury, Motor Vehicle Accident, fall from a height) and in $20 \%$ were secondary to low energy trauma (fall). The revealing clinical presentation is described in table 1 .

Fractures are classified according to the classification of Anderson and D'Alonzo [4]. The postoperative clinical evolution was studied according to the modified Rankin scale (mRS) (Table 1).

\begin{tabular}{|l|l|}
\hline Score & Description \\
\hline 0 & No symptoms at all \\
\hline 1 & $\begin{array}{l}\text { No significantly disability despite symptoms; able to } \\
\text { carry out all usual duties and activites }\end{array}$ \\
\hline 2 & $\begin{array}{l}\text { Slight disability; unable to carry out all previous } \\
\text { activities, but able to look after own affairs without } \\
\text { assistance }\end{array}$ \\
\hline 3 & $\begin{array}{l}\text { Moderately disability; requiring some help, but able to } \\
\text { walk without assistance }\end{array}$ \\
\hline 4 & $\begin{array}{l}\text { Moderately severe disability; unable to walk without } \\
\text { assistance and unable to attend the own bodily needs } \\
\text { without assistance }\end{array}$ \\
\hline 5 & $\begin{array}{l}\text { Severe disability, bedridden, incontinent and requiring } \\
\text { constant nursing care and attention }\end{array}$ \\
\hline 6 & Death \\
\hline
\end{tabular}

Table 1: modified Rankin Scale.

"Corresponding Author: Dr. Noukhoum Koné, Department of neurosurgery, Kiffa Hospital Center, Mailbox 4509 Kiffa, Mauritania, Tel: (00222) 34084244; Email: colo10fr@hotmail.com

Citation: Koné N, Haidara A, Giamundo M, Rusconi A (2018) Management of Type II Odontoid Fractures OBAV: About A Series of 5 Cases and Literature Review. Int J Surg Surgical Porced 3: 130. https://doi.org/10.15344/2456$4443 / 2018 / 130$

Copyright: (C) 2018 Koné et al. This is an open-access article distributed under the terms of the Creative Commons Attribution License, which permits unrestricted use, distribution, and reproduction in any medium, provided the original author and source are credited. 
Citation: Koné N, Haidara A, Giamundo M, Rusconi A (2018) Management of Type II Odontoid Fractures OBAV: About A Series of 5 Cases and Literature Review. Int J Surg Surgical Porced 3: 130. https://doi.org/10.15344/2456-4443/2018/130

\section{Surgical technique}

Posterior screw fixation was performed using $3.5 \times 24 \mathrm{~mm}$ or $4.0 \times$ $30 \mathrm{~mm}$ polyaxial screws. Screws were inserted bilaterally into the C-1 lateral masses and C-2 pedicles, as described by Harms and Melcher [9].

Titanium rods ( $3.5 \mathrm{~mm}$ in diameter) were fixed to the connectors on the $\mathrm{C} 1$ and $\mathrm{C}-2$ screw heads with locking nuts (Figure 1).

The screw-hook-rod construct consisted of a hook and a screw interconnected on a single rod (Figure 2). The hooks were inserted in contact with the caudal border of the $\mathrm{C} 2$ lamina, as laterally as possible from midline, to facilitate the connection of the rods.

\section{Results}

All patients were surgically treated posteriorly (Table 2). The mean follow-up was 10 months. Clinical outcome was improved in all cases. Bony fusion at lateral-view and openmouth view on Xrays was considered good in 4 patients. We observed a case of an infection of the surgical site resolved under antibiotics.

\section{Discussion}

Like our series the causes of these injuries are, falls in the elderly or high-velocity accidents in the young and middle-aged. The fracture mechanism is hyperextension or hyperflexion of the cervical spine. The incidence of neurological involvement after odontoid fracture has been reported to be between $0 \%$ and $27 \%[4,15,16]$. Neck pain is the main symptom. Plain radiography remains the mainstay for identification of odontoid fractures [17,18]. Both lateral-view and openmouth view radiography may demonstrate the fracture. The magnitude and direction of displacement should be noted because this may be related to failed bone union when nonoperative management is undertaken. In addition, the ligamentous stability of the atlantoaxial joint can be estimated by measuring the atlantodental interval. Fielding and al. [19], have suggested that a greater than 3 $\mathrm{mm}$ separation between the anterior $\mathrm{C}-1$ ring and the dens implies possible transverse ligament disruption. In addition, Spence et al. [20], have suggested that when the lateral masses of the atlas overhang the superior articular facets of the axis by more than $7 \mathrm{~mm}$, injury of this ligament may similarly occur.

The use of CT scanning may be quite helpful in demonstrating the plane of the fracture line as well as the degree of comminution [18]. Both sagittal and coronal CT reconstructions often delineate the fractures more precisely than plain radiographs. However, CT scanning occasionally fails to demonstrate a fracture in the transverse plane if the gantry angle is parallel to the fracture line. MRI has a more limited role in evaluating patients who have sustained odontoid fractures without neurological injuries [18]. However, evaluation of the integrity of the transverse ligament can be facilitated using MRI. Multiplanar gradient echo modalities have successfully demonstrated disruption of this ligament, prompting operative treatment rather than applications of external immobilization devices alone.

The optimal treatment of TOF is controversial. Nonsurgical treatment with a cervical collar or halo vest has a nonunion rate of as high as $40 \%$ [21]. For this reason, surgical treatment is especially indicated in patients who have a higher risk for nonunion. In this

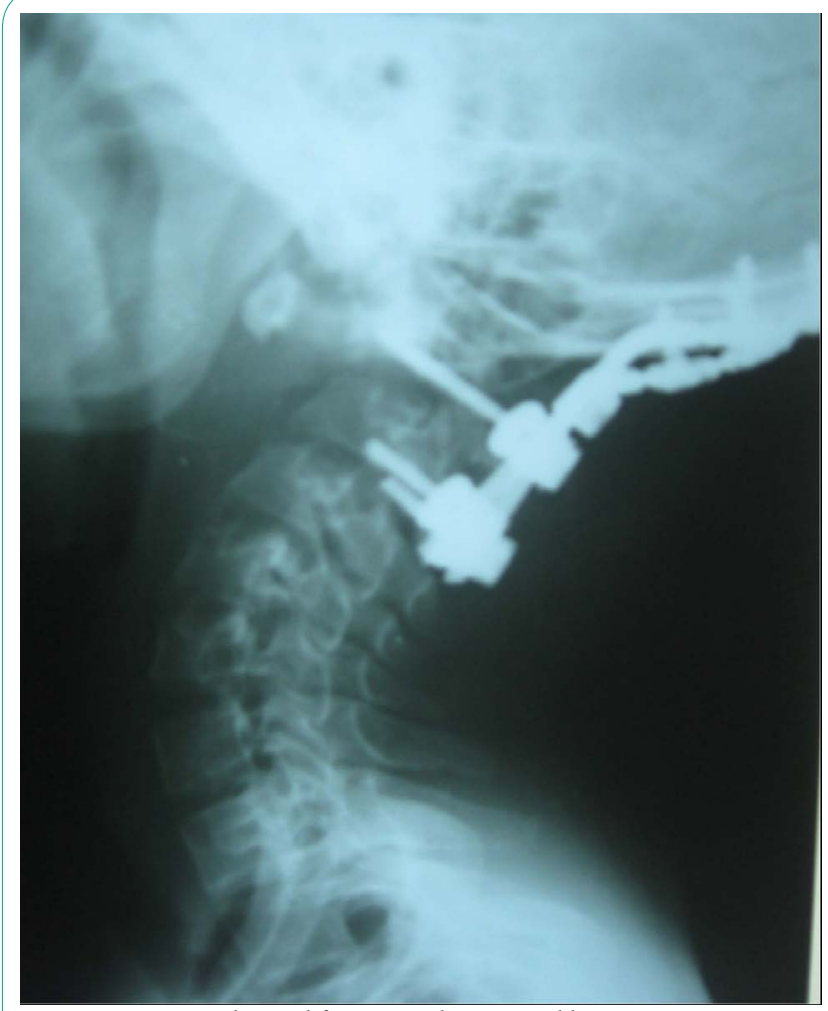

Figure 1: Type II odontoid fracture, Obar, treated by posterior approach. Cervical profile radiograph showing the screw-rod technique interconnecting polyaxial screws at $\mathrm{C} 1$ and $\mathrm{C} 2$ (Harms's technique); and screws at occiput with rods.

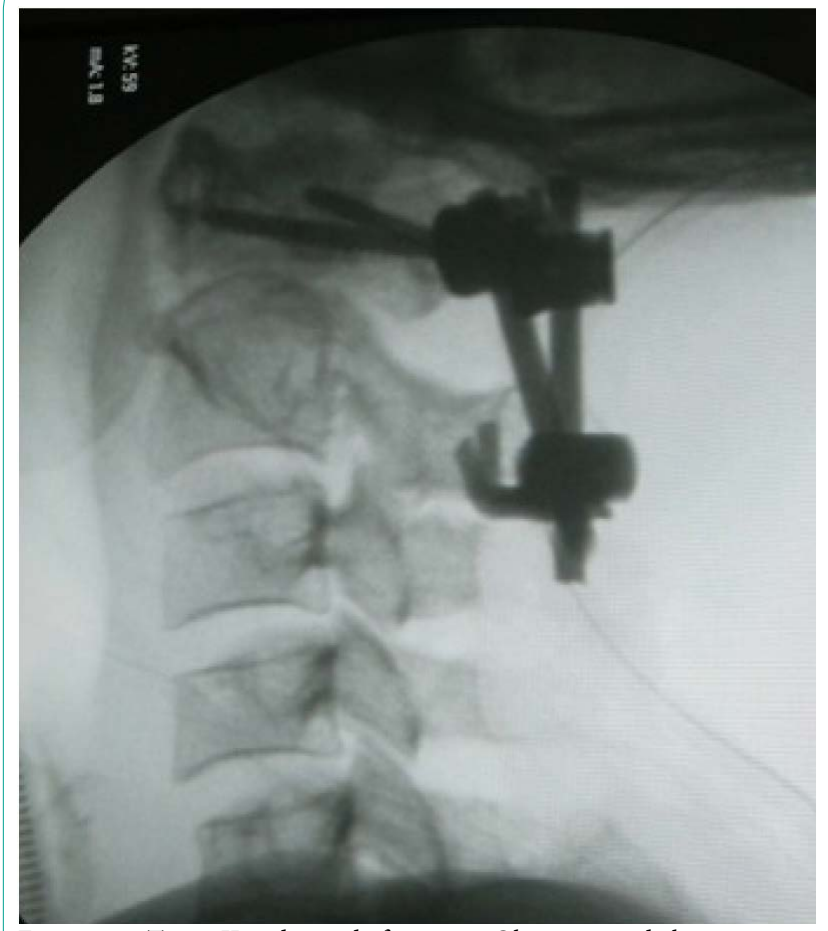

Figure 2: Type II odontoid fracture, Obav, treated by posterior approach. Cervical profile radiograph the screw-hook-rod technique interconnecting polyaxial screws at $\mathrm{C} 1$ and hook inserted in contact with the caudal border of $\mathrm{C} 2$ lamina with rods. 
Citation: Koné N, Haidara A, Giamundo M, Rusconi A (2018) Management of Type II Odontoid Fractures OBAV: About A Series of 5 Cases and Literature Review. Int J Surg Surgical Porced 3: 130. https://doi.org/10.15344/2456-4443/2018/130

Page 3 of 4

\begin{tabular}{|c|c|c|c|c|c|c|c|c|c|c|}
\hline Patients & Sex & Age(Yrs) & Mechanisim & Type & $\begin{array}{l}\text { Associated } \\
\text { lesions }\end{array}$ & $\begin{array}{c}\text { Revealing } \\
\text { Symptomatologies }\end{array}$ & $\begin{array}{l}\text { Treatment } \\
\text { Modality }\end{array}$ & Laminectomy & Month & Complications \\
\hline 1 & $\mathrm{M}$ & 29 & Inl & II Obav & No & $\begin{array}{l}\text { Cervicalgia, Arnold's } \\
\text { neuralgia, Tetraparesia }\end{array}$ & $\begin{array}{l}\text { C1 latered mass/ } \\
\text { C2 laminar hooks }\end{array}$ & no & 0 & no \\
\hline 2 & $\mathrm{M}$ & 52 & MVA & II Obav & No & $\begin{array}{l}\text { Cervicalgia, } \\
\text { Tetraparesia }\end{array}$ & $\begin{array}{l}\text { C1 latered mass/ } \\
\text { C2 laminar hooks }\end{array}$ & no & 0 & no \\
\hline 3 & M & 74 & MVA & II Obav & No & $\begin{array}{l}\text { Cervicalgia, } \\
\text { hemiparesia }\end{array}$ & $\begin{array}{l}\text { C1 latered mass/ } \\
\text { C2 pedide screws }\end{array}$ & $\mathrm{C} 1$ & 1 & no \\
\hline 4 & M & 75 & fall & II Obav & $\begin{array}{l}\text { Luxcation } \\
\text { C1C2 }\end{array}$ & $\begin{array}{l}\text { Cervicalgia, Arnold's } \\
\text { neuralgia, } \\
\text { swallowing disorder }\end{array}$ & $\begin{array}{l}\text { C1 latered mass/ } \\
\text { C2 pedide screws }\end{array}$ & $\mathrm{C} 1, \mathrm{C} 2$ & 1 & no \\
\hline 5 & M & 16 & fall & II Obav & $\begin{array}{l}\text { Luxcation } \\
\text { C0C2 }\end{array}$ & $\begin{array}{l}\text { Cervicalgia, } \\
\text { Tetraparesia }\end{array}$ & $\begin{array}{l}\text { Ocipital screws/ } \\
\text { C1 latered mass/ } \\
\text { C2 pedide screws }\end{array}$ & $\mathrm{C} 1$ & 0 & $\begin{array}{l}\text { surgical site } \\
\text { infection }\end{array}$ \\
\hline
\end{tabular}

Table 2: Clinical data summary of patients included in the study.

InI: Intentional Injury, MVA: Motor Vehicle Accident, OBAV: Fracture line Oblique from posterosuperior to anteroinferior

context, surgical treatment with posterior cervical instrumented fusion increases the fusion rate to more than $80 \%$ in many patient series $[21,22]$.

The posterior surgical approach represent $[8,9]$ a good technique for the management of TOF OBAV.

Some authors have reported up to $98-100 \%$ healing with posterior C1-2 arthrodesis [9,22-25].

Using C-1 lateral mass screws and C-2 pedicle screws with a polyaxial screw/rod system like 3 cases of our study is favored by some authors $[9,24]$ and has a low complication rate.

Our novel screw-hook-rod construct consisted of a hook and a screw interconnected on a single rod. It is an especially attractive option in osteopenic patients, where screw pullout would be a concern.

The screw-hook-rod technique like the standard Harms technique, making it an acceptable alternative technique when aberrant arterial anatomy precludes the placement of $\mathrm{C} 1-2$ transarticular screws.

In a human cadaver study, Fagerström and al. [26] found that $95 \%$ of 77 cervical laminar hooks placed, no deformation of the dural sac was observed and there was no evidence of spinal cord compression.

Winter [27] reviewed the risk factors for spinal cord injury during cervical spine surgery and pointed out that direct trauma to the spinal cord caused by hooks was a hazard. Using of hook does require intact posterior elements [28]. Our two procedures can be performed in all cases of TOF OBAV where the lateral mass are normal.

Compared with a posterior laminar hook procedure, the screw/ rod system does not require intact posterior elements, which can be disrupted in conditions such as trauma [29].

The transarticular screw system does not require intact posterior elements; however in the litterature review [23] the incidence of malpositioned screws and vertebral artery injuries was 1.4 and $1.7 \%$, respectively after atlantoaxial transarticular screw fixation.

We found no previous study tested the C1 screw and C2 hook-rod technique in the litterature.
Further others studies will be necessary to evaluate this procedure (C1 screw and C2 hook-rod technique) and compare to others posterior procedures.

\section{Conclusion}

The screw-hook-rod technique like the standard Harms technique, making it an acceptable alternative surgical procedure for TOF OBAV. Surgeons might consider theses differents approachs techniques before realizing a treatment.

\section{Competing Interests}

The authors declare that they have no competing interests.

\section{Authors' Contributions}

All authors contributed to the design, analysis and interpretation of the data, the writing of the article or the critical revision of its intellectual content. All authors have read and approved the final version of the manuscript.

\section{References}

1. Ersmark H, Lowenhielm $P$ (1988) Factors influencing the outcome of cervical spine injuries. J Trauma 28: 407-410.

2. Fujii E, Kobayashi K, Hirabayashi K (1988) Treatment in fractures of the odontoid process. Spine (Phila Pa 1976) 13: 604-609.

3. Husby J, Sorensen KH (1974) Fractures of the odontoid process of the axis. Acta Orthop Scand 45: 182-192.

4. Anderson LD, D'Alonzo RT (1974) Fractures of the odontoid process of the axis. J Bone Joint Surg Am 56: 1663-1674.

5. Clark CR, White AA (1985) Fractures of the dens. A multicenter study. J Bone Joint Surg Am 67: 1340-1348.

6. Mouradian WH, Fietti VG Jr, Cochran GV, Fielding JW, Young J, et al. (1978) Fractures of the odontoid: a laboratory and clinical study of mechanisms. Orthop Clin North Am 9: 985-1001.

7. Hadley MN, Walters BC, Grabb PA, Oyesiku NM, Przybylski GJ, et al (2002) Isolated fractures of the axis in adults. Neurosurgery 50: S125-S139.

8. Goel A, Laheri V (1994) Plate and screw fixation for atlanto-axial subluxation. Acta Neurochir (Wien) 129: 47-53.

9. Harms J, Melcher RP (2001) Posterior C1-C2 fusion with polyaxial screw and rod fixation. Spine (Phila Pa 1976) 26: 2467-2471. 
Citation: Koné N, Haidara A, Giamundo M, Rusconi A (2018) Management of Type II Odontoid Fractures OBAV: About A Series of 5 Cases and Literature Review. Int J Surg Surgical Porced 3: 130. https://doi.org/10.15344/2456-4443/2018/130

10. Reis MT, Nottmeier EW, Reyes PM, Baek S, Crawford NR (2012) Biomechanical analysis of a novel hook-screw technique for C1-2 stabilization J Neurosurg Spine 17: 220-226.

11. Majercik S, Tashjian RZ, Biffl WL, Harrington DT, Cioffi WG (2005) Halo vest immobilization in the elderly: a death sentence? J Trauma 59: 350358.

12. Koivikko MP, Kiuru MJ, Koskinen SK, Myllynen P, Santavirta S, et al (2004) Factors associated with nonunion in conservatively- treated type-I fractures of the odontoid process. J Bone Joint Surg Br 86: 1146-1151.

13. Traynelis VC (1997) Evidence-based management of type II odontoid fractures. Clin Neurosurg 44: 41-49.

14. Przybylski GJ (2000) Introduction to odontoid fractures: controversies in the management of odontoid fractures Neurosurg Focus 8 (6): Introduction, 2000

15. Greene KA, Dickman CA, Marciano FF, Drabier JB, Hadley MN, et al (1997) Acute axis fractures. Analysis of management and outcome in 340 consecutive cases. Spine (Phila Pa 1976) 22: 1843-1852.

16. Hadley MN, Dickman CA, Browner CM, Sonntag VK (1989) Acute axis fractures: a review of 229 cases. J Neurosurg 71: 642-647.

17. Althoff $B$ (1979) Fracture of the odontoid process. A clinical and radiographic study. Acta Orthop Scand Suppl 177: 1-95.

18. Ehara S, el-Khoury GY, Clark CR (1992) Radiologic evaluation of dens fracture. Role of plain radiography and tomography. Spine (Phila Pa 1976) 17: $475-479$

19. Fielding JW, Cochran Gv, Lawsing JF 3rd, Hohl M (1974) Tears of the transverse ligament of the atlas: a clinical and biomechanical study. J Bone Joint Surg Am 56: 1683-1691.

20. Spence KF Jr, Decker S, sell KW (1970) Bursting atlantal fracture associated with rupture of the transverse ligament. J Bone Joint Surg Am 52: 543-49.

21. Robinson $Y$, Robinson AL, Olerud C (2014) Systematic review on surgical and nonsurgical treatment of type II odontoid fractures in the elderly. Biomed Res Int 2014: 231948.

22. Aebi M, Etter C, Coscia M (1989) Fractures of the odontoid process Treatment with anterior screw fixation. Spine (Phila Pa 1976) 14: 10651070

23. Gluf WM, Schmidt MH, Apfelbaum RI (2005) Atlantoaxial transarticular screw fixation: a review of surgical indications, fusion rate, complications, and lessons learned in 191 adult patients. J Neurosurg Spine 2: 155-163.

24. Aryan HE, Newman CB, Nottmeier EW, Acosta FL Jr, Wang VY, et al (2008) Stabilization of the atlantoaxial complex via C-1 lateral mass and $\mathrm{C}-2$ pedicle screw fixation in a multicenter clinical experience in 102 patients: modification of the Harms and Goel techniques. J Neurosurg Spine 8: 222-229.

25. Maciejczak A, Wolan-Nieroda A ska-Sudoł K (2015) Comparison of fusion rates between rod-based laminar claw hook and posterior cervical screw constructs in Type II odontoid fractures Injury. Int J Care Injured 46: 13041310.

26. Fagerström T, Hedlund R, Bancel P, Robert R, Dupas B (2001) Laminar hook instrumentation in the cervical spine. An experimental study on the relation of hooks to the spinal cord. Eur Spine J 10: 340-344.

27. Winter RB (1997) Neurologic safety in spinal deformity surgery. Spine (Phila Pa 1976) 22: 1527-1533

28. Sen MK, Steffen T, Beckman L, Tsantrizos A, Reindl R, et al. (2005) Atlantoaxial fusion using anterior transarticular screw fixation of C1-C2 technical innovation and biomechanical study. Eur Spine J 14: 512-518.

29. Bertand G (1982) Anomalies of the craniovertebral junction. In: youmans JR (ed) Neurological surgery: a comprehensive reference guide to the diagnosis and and management of neurosurgical problems. 2nd Ed, vol 3. Saunders, Philadelphia, p1496. 